\title{
The Influence of Work Environment on Employee Retention: Empirical Evidence from Banking Institutions in Dar Es Salaam, Tanzania
}

\author{
Amos Ephraim Hanai \\ A Freelance Management Consultant - Dar es Salaam, Tanzania
}

*Corresponding Author: Amos Ephraim Hanai, A Freelance Management Consultant - Dar es Salaam Tanzania

\begin{abstract}
This study aimed at investigating the influence of work environment on employee retention in the banking institutions of Tanzania, particularly in Dar es Salaam region. A survey design was employed in the study. Stratified sampling was used to ensure representativeness of banks classified in terms of bank category.Eleven banks were purposely selected and simple random sampling was applied to draw a sample of 370 employees. The quantitative data were collected using questionnaire and analyzed using Binary logistic regression. The results indicated that work environment significantly influenced employee retention with a ' $p$ ' value of 0.001. It was further revealed that work environment attributes (responsibility for the job and bank reputation) have significant influence on employee retention. The study recommends to the bank managers to develop and implement retention policies that contemplate responsibility and bank reputation as these were the most valued attributes. The bank managers also need to pay attention to the right retention policies in order to improve retention of employees.
\end{abstract}

Keywords: Work environment, Employee retention, Banking institution

\section{INTRODUCTION}

Employee retention has become a major concern in many organizations in recent years (Manogharan, et al., 2018).Mir and Mufeed (2016) contend that today's business environment is very competitive thus making skilled and experienced employees important to organizations. Thirupathy and Dhayalan (2016) argued that skilled employees are the major differentiating factor for most organizations in today's competitive business environment.Samuel and Chipunza (2009) indicated that retention of skilled employees is important for sustaining competition and ensuring effective and efficient service delivery in organizations. On the other hand,Ibidunni, et al. (2016) argued that, employee retention helps in improving organizational performance. Hence, employee retention is regarded as crucial for organizational performance as well as competitiveness in today's world of competition in business.

In Tanzania, competition in banking business started to emerge soon after liberalization of the economy in 1980s and financial sector reforms in 1990s which allowed private banks to operate in the country. As a result, the number of banks increased from four prior liberalization (Mboya, 2012) to fifty eight by the end of December 2017 (Bank of Tanzania, 2017). The increase of banks particularly in Dar es Salaam region, resulted a competitive business environment and dynamic market in the banking industry in Tanzania. This in turn resulted a problem in retaining employees especially reputable ones (Mboya, 2012; Kweka and Sedoyeka, 2014). Many organizations including banking institutions have taken initiatives in order to improve employee retention (Ibidunni, et al., 2016; Msisiri and Juma, 2017) after realizing the importance of employee retention and its benefits such as improved organizational performance. Banking institutions in Tanzania also took initiatives and adopted various retention strategies to ensure their employees are retained.

Despite available evidence on the benefits of employee retention from empirical literature and initiatives taken by organizations/banks in improving employee retention, still there is a problem of retaining desirable employees. This may suggest that the initiatives taken and the implemented retention strategies might have been done with limited understanding of the key factors of employee 
retention in the context of banking industry in Tanzania. If the problem of retaining desirable employees is not resolved, it has many negative consequences in the performance and operation of the bank. For instance, in the Indian context, Shahin (2017) contended that poor employee retention can lead to many operational problems, decreasing morale and increase in cost to the organization due to new recruitments and training new employees. In the Tanzanian context, Oyagi and Kembu (2014) argued that poor retention of employees imposes many costs such as costs of recruitment, training new employees and additional burden of work on remaining employees. Based on this perspective, it is important to understand the factors that influence employee retention among banks. This study therefore, intended to understand the influence of work environment on employee retention among banking institutions in Dar es Salaam region.

However the benefits and impact associated with employee retention, many banks in Tanzania, especially in Dar es Salaam region are experiencing problem in retaining employees (Mboya, 2012; Mwita, et al., 2018). Despite the problem which affects banking performance, little has been done in empirical literature in addressing employee retention issues related to work environment. Even those few studies that were done in the country, most of them came up with different attributes of work environment that influence employee retention. For instance, Muhoho (2014) revealed that organizational justice and organizational prestige as work environment attributes that strongly influenced employee retention but neglected other attributes such as work life balance and recognition that were identified by Msisiri and Juma (2017).

Given the inconsistencefindings in the literature and the problem of retaining employees which affects negatively the banking performance, the current study fills this gap by investigating the influence of work environment on employee retention among banking institutions in Dar es Salaam. The study also shed light on the inconsistenceconclusions on the attributes of work environment drawn in the previous studies on employee retention. Hence, the current study formulated one research hypothesis to be addressed, that is, "Work environment hasa significant influence on employee retention among banking institutions in Dar es Salaam region".

\section{LITERATURE REVIEW}

\subsection{Theoretical Literature Review}

The concept of employee retention has been defined by several scholars to fit their context of study. Zareen, et al. (2013) defined employee retention as the ability of an organization to retain its employees. Other scholars like Msengeti and Obwogi (2015) defined employee retention as the efforts by any business or organization to develop strategies and initiatives that support current staff into remaining with the organization. The current study adopted the definition introduced by Gayathri, et al. (2012) who defined employee retention as a process in which employees are encouraged to stay with the organization for the maximum period of time or until the completion of the project. Despite the literature clearly evidenced that there is no single factor for employee retention(Regina and Rosalia, 2015), this study focused on investigating the influence of work environment on employee retention among banking institutions in Dar es Salaam region, Tanzania.

Jain and Kaur (2014) stated that work environment involves all the physical, psychological and social aspects which act and react on the body and mind of an employee. Other scholars such as Markey, et al. (2012), expressed that, work environment encompasses the physical aspects, psycho-social and organizational surroundings of work but does not focus on individual employee or job characteristics. Basing on these definitions of work environment, the construct can be broken down into work environment attributes such as communication, stress, work pressure, creativity, fairness, recognition, co-worker relation, supervisor relation, control over work, flexible working, performance appraisal, working conditions, responsibility for the job, supervision, job security, work itself, organization reputation, policies and administration, etc. These attributes of work environment can have influence on employee retention in an organization. This pushes organizations to ensure that good work environment is maintained in order to influence employees to stay instead of leaving. These attributes can therefore be selected and used to measure the construct.

Herzberg (1966) two factor theory provided a theoretical background for this study as the factor, that is, work environment was borrowed from the theory. The theory states that there are certain factors in 
the workplace that cause job satisfaction (and motivation) while a separate set of factors that cause dissatisfaction. According to Herzberg (1966) two factor theory, motivation of employees at workplace would occur only as a result of the use of motivators such as achievement, responsibility, the work itself, recognition, advancement and growth.

This is contrasted with a second set of factors called hygiene factors such as company policy and administration, interpersonal relations, salary, supervision, job security and working conditions, as the use of these factors at workplace would not motivate or create satisfaction to employees. Instead it would result in a neutral state (Herzberg, 1966). Despite that Herzberg two factor theory is a motivation theory which was developed to study employee motivation at workplaces, but in the current study the theory was considered relevant on studying employee retention. The relevance of this theory was based on evidence from the empirical literature (Motlou and Karodia, 2016; Waweru and Kagiri, 2018) that when employees are motivated or satisfied at work, they are likely to stay in the organization.

A number of empirical studies (Thirupathy and Dhayalan, 2016; Chen, et al., 2017) have well evidenced the applicability of Herzberg (1966) two factor theory in studying employee retention. For example, Chen, et al. (2017)studied employee retention in Malaysia using Herzberg two factor theory, and indicated pay and compensation, and career advancement as important predictors that influenced employee retention. Adzei and Atinga (2012) who applied Herzberg two factor theory to study the link between motivation and employee retention, indicated a strong link between the two. The study by Oyagi and Kembu (2014) in Tanzania grounded on Herzberg two factor theory found that motivational variables like work environment have positive and significant influence on retention of academic staff. This theory therefore, helped to inform the study on the influence of work environment on employee retention at the banking institutions in Dar es Salaam region.

\subsection{Empirical Literature Review}

\subsubsection{Work Environment and Employee Retention}

In the Pakistan context, Kanwal and Majid (2013)who studied retention management in banking system of Multan in Pakistan, revealed that, long working hours and lack of effective communication between employees and employers at the work place have significant impact on employee retention. Gangwani and Dubey (2016) carried out a study on influence of working environment on employee retention in India. Using regression analysis, the study revealed a positive relationship between work environment and employee retention. Ahmada, et al. (2015) indicated that recognition and annual performance appraisal significantly contributed on retention of employees in the banking sector of Pakistan. The study also recommended that, more flexible working hours and safer good working environment be established by the management in order to retain employees.

Tansuria and Nelwan (2018) indicated that performance management, employee engagement, social support, organizational culture and work environment significantly contribute in retention of employees at the university in East Indonesia. The study applied purposive sampling in selecting research participants, and this type of non-probability sampling may have not represented enough the Indonesian population working in tertiary educational institutions. To avoid this kind of weakness of non-probability sampling which was used by the study, the current study used stratified sampling and simple random sampling. It was considered that these sampling techniques can provide more reliable results based on a more representative sample to the population.

Other scholars (Patel and Patel, 2014) also showed that work environment is significantly related to employee retention. Nasir and Mahmood (2016) researched on determinants of employee retention in Pakistan and argued that work-life balance, job satisfaction, work environment, recognition and supervisor support are significantly correlated with employee retention. Roy (2018) who did a study in the banking industry in India, revealed a significant relationship between work-life balance and employee retention. In the context of Pakistan, Malik, et al. (2018) argued that co-worker support and supervisor support have significant and direct relationship with employee retention. Hong, et al. (2012) observed a significant relationship between performance appraisal and employee retention. In contrary, Imna and Hassan (2015) revealed insignificant influence of performance appraisal on employee retention. These studies indicated different attributes of work environment that influence 
The Influence of Work Environment on Employee Retention: Empirical Evidence from Banking Institutions in Dar Es Salaam, Tanzania

retention while some studies revealed insignificant influence of the attributes on employee retention. This contradiction in the findings calls for more research in the subject area to establish what might have contributed to these contradictions.

In the African perspective, Reddy and Govender (2014) revealed that flexible working hours and a more meaningful and challenging work environment as important in retaining workers at a leading bank in South Africa. In a banking context of Sudan, Mohamed, et al. (2017) revealed that work environment contributes to employee retention. In the Tanzanian context, Oyagi and Kembu (2014) found that recognition, job security and work environment have positive and significant influence on employee retention. In a related perspective, Msisiri and Juma (2017) found a significant relationship between work environment, work-life balance and recognition and employee retention in CRDB bank in Arusha region, Tanzania. The review of these empirical studies, have evidenced a relationship between work environment and employee retention.

Most previous studies as cited above have indicated the relationship between work environment with employee retention. However, contrary results from empirical studies which indicated insignificant influence of some work environmentattributes like performance appraisal on employee retention were also observed. These contrary resultsmighthave been due to the fact that sensitivity levels, satisfaction levels, perceptions, attitudes, behaviours and needs of every employee aredifferent (Zareen et al., 2013). This may imply that more research is needed with careful selection of indicator variables in studying the influence of work environment on employee retention. This may also raise a need for investigating further the needs, perceptions, sensitivity levels and satisfaction levels of employees as these also can have impact with respect to employee retention. For example, some employees are very sensitive, so they can be very difficult to retain in an organization.

\subsection{Conceptual Framework}

The study developed a conceptual framework based on the literature review above. One dependent variable namely Employee Retention (ER) and one independent variable namely Work Environment(WE) were used to develop a conceptual framework as described in figure 1.0 below.

Independent variables

Dependent variable

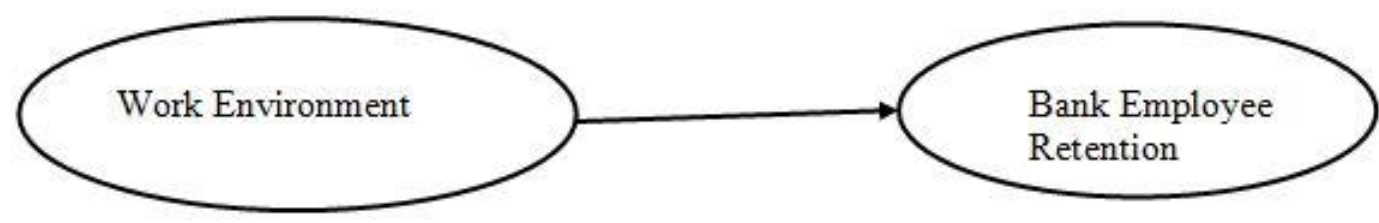

Figure1. Conceptual Framework for the study

Source: Author based on literature review (2020)

\section{RESEARCH METHODOLOGY}

Quantitative method was used in this study. The positivism philosophy was also adopted in the study as the developed hypothesis and proposed model can be tested to explain the influence of work environment on employee retention among banking institutions in Dar es Salaam region. According to Lancaster (2005) positivism philosophy assumes that the researcher is independent, concentrates on facts by testing hypothesis and there are no human interests on the study. The study used the survey strategy and employed explanatory research design. The explanatory design helped to test the existence of relationships among variables and validated a model which can be used to explain employee retention in the banks. The rationale to use explanatory design was based on its usefulness in explaining causal relationship among variables and to produce a model for these relationships.

Data was collected in Dar es Salaam region. The selected study area was based on the reason that all banking institutions are operating in the region and that there is no any other region in the country where all these banks are operating. High competition in banking business was also experienced in the study area which in turn influences competition in retaining skilled bankers. So, the study managed to 
get required data to understand the influence of work environment on employee retention among the banks.

Stratified sampling was used to ensure representativeness of banks classified in terms of bank category. Eleven banks were selected purposely to ensure representation of each category in the sample. Simple random sampling was then used to draw a sample of 370employees from selected sample banks. The overall sample size was allocated proportionally among the eleven sampled banks depending on their number of employees.

To ensure the suitability of data collection instrument, the study conducted a pilot study before the main survey. Data analysis was done using both descriptive and inferential analysis. Binary logistic regression analysis was used to test a hypothesis and to develop a model on work environment that can explain employee retention among banking institutions in Dar es Salaam.

\section{FINDINGS}

\subsection{Descriptive Data Analysis}

The frequency and percentage were used in the descriptive data analysis in order to profile and gain an understanding of various respondents' characteristics.

\section{Gender of the Respondents}

The findings on gender of the respondents indicated that female respondents were slightly higher than male respondents as among the 326 respondents contacted, $41.1 \%$ were male and $58.9 \%$ were female. This proportional of the percentage indicates representation of gender in the study as the data captured in figure 2.0.

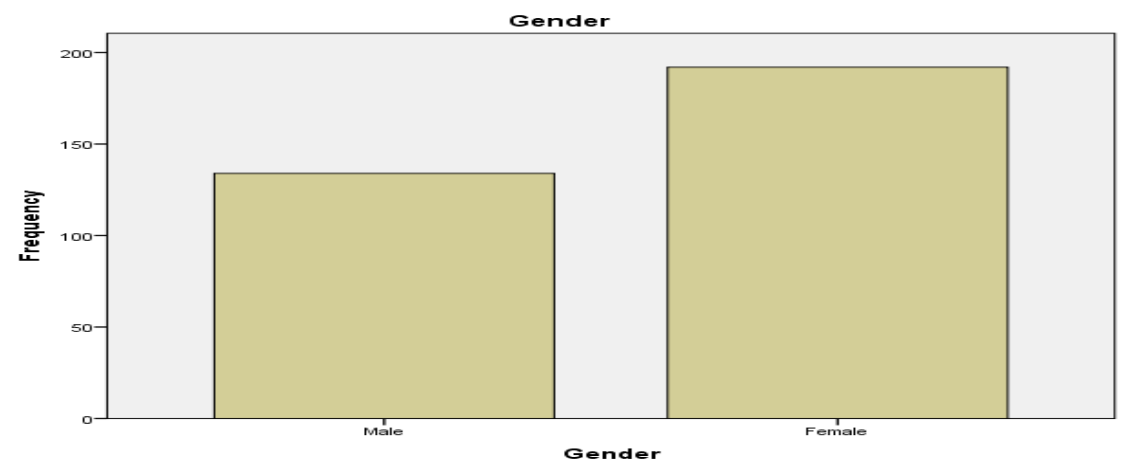

Figure2. Gender representation

Age of the Respondents

The age groups were as follows; $30.7 \%$ were aged between $20-30$ years, $48.5 \%$ were aged between 30 - 40 years, $14.7 \%$ were aged between 40 - 50 years and $6.1 \%$ were aged between 50 - 60 years as indicated in figure 3.0.

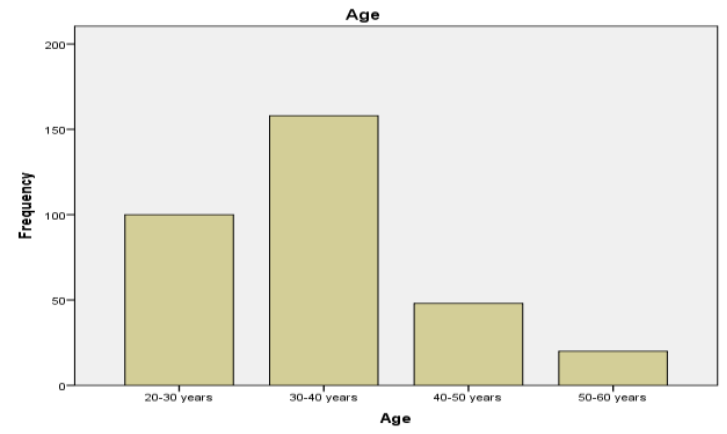

Figure3. Age frequencies

The Respondents' Level of Education 
The findings on the level of education indicated that the majority $(66.6 \%)$ had first degree or its equivalent (Bachelor's degree), $(27 \%)$ had postgraduate degrees, $(4.6 \%)$ had qualification higher than secondary schools (Diploma) while a few (1.8\%) had secondary education qualifications. Majority of the respondents involved had good level of education as summarised in figure 4.0.

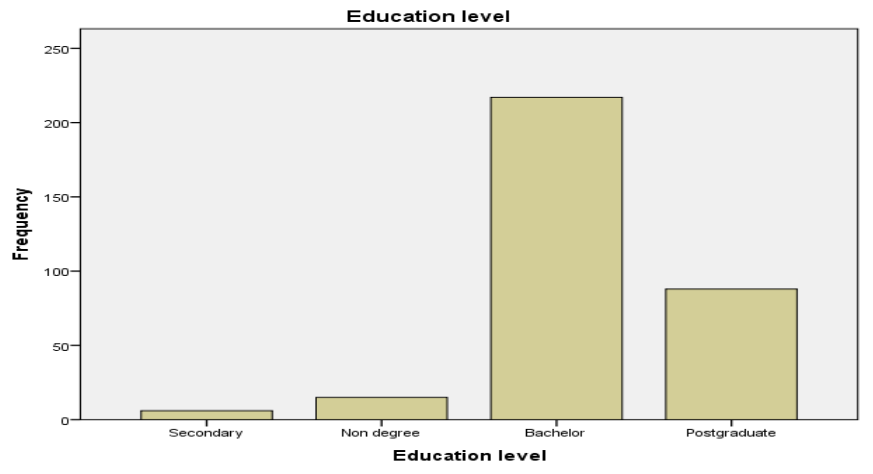

Figure4. Respondents education level

\section{Marital Status of the Respondents}

The study revealed that $57.7 \%$ were married, $38 \%$ were single, $2.1 \%$ were widow and $2.1 \%$ were divorced/separated. Majority of respondents were married and single, however the proportional of the percentage indicated representation as shown in figure 5.0.

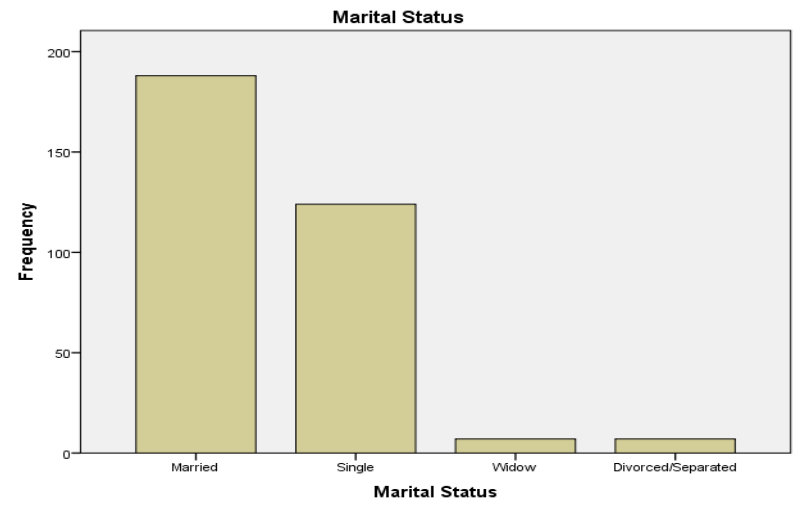

Figure5. Respondent's marital status

\section{Management Level of the respondents}

The findings indicated that majority of the banks staff $(60.4 \%)$ were non-management employees, (37.1\%) were mid-level management employees while a few $(2.5 \%)$ were top management employees. Each management level was involved in the study as it was considered that each tier may have different need that may influence a decision to stay (Uitzinger, et al., 2016) as summarized in figure 6.0.

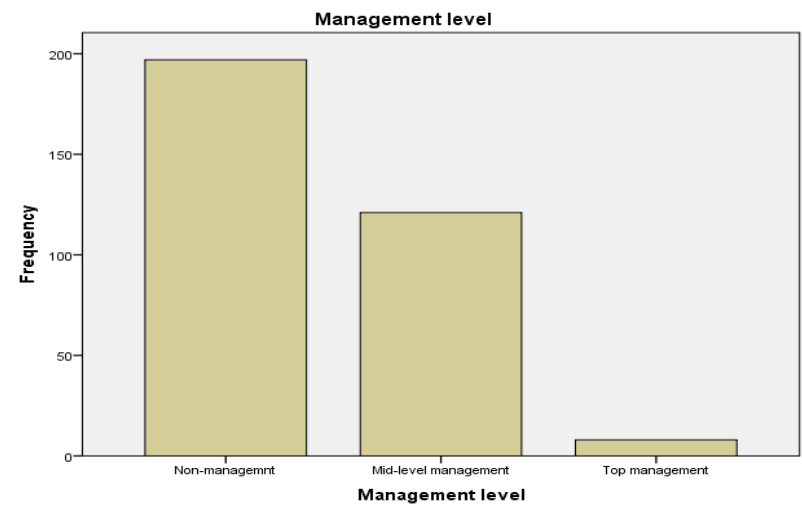

Figure6. The banks management levels 
The Influence of Work Environment on Employee Retention: Empirical Evidence from Banking Institutions in Dar Es Salaam, Tanzania

\section{The Banks Respondents Work Experiences}

The study results revealed that out of 326 respondents, 5.2\% had worked less than 1 year, $46.9 \%$ had worked from 1 to less than 5 years, 29.4\% have worked from 5 to less than 10 years and $18.4 \%$ have worked above 10 years. The data covered each group category as the study considered that the number of years an employee has worked may have influence on their decision to stay as argued by (Agyeman and Ponniah, 2014). Figure 7.0 shows frequencies for the banks employees working experiences.

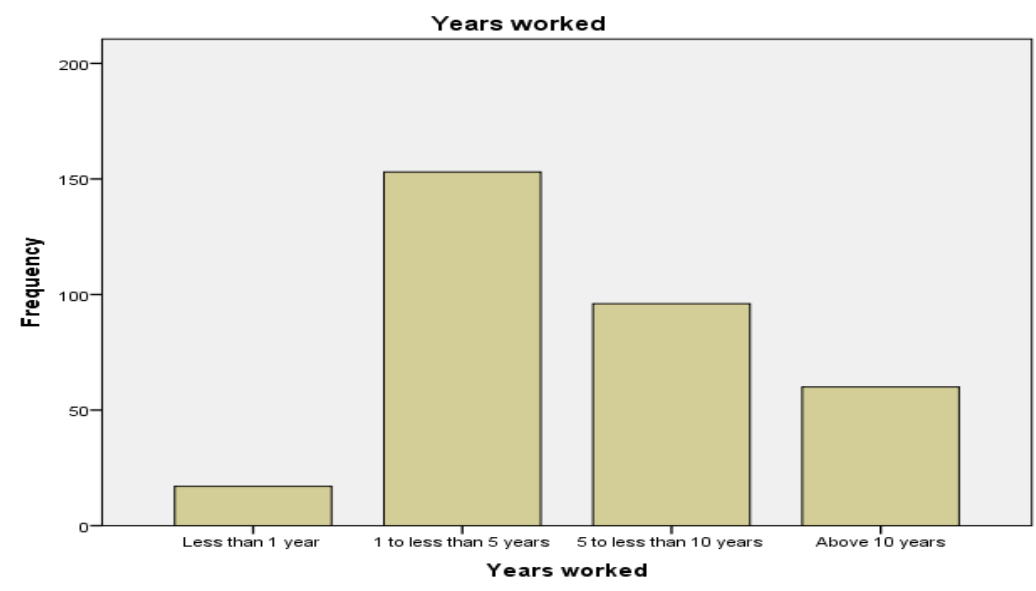

Figure7. Bank respondents work experiences

\subsection{Validity and Reliability}

Validity and reliability issues were considered in testing the trustworthiness of the measurement instrument (Ihantola and Kihn, 2011). Content validity, construct validity and criterion validity were observed in ensuring validity (Drost, 2011). A pilot study of survey instrument was done in order to ensure that the items in the questionnaire accurately reflect the theoretical domain of the latent construct it claims to measure. This involved few experts in human resource especially in work environment aspects and few respondents as a sample population to help the study to strengthen the measurement instrument.

To ensure construct validity, correct operational measures for the work environment (WE) construct were identified. To ensure criterion validity, the data collection instrument was drawn and developed by considering strong validated literature and expert panels. Kimberlin and Winterstein (2008) argue that criterion validity provides evidence about how well scores on the new measure correlate with other measures of the same construct or very similar underlying constructs that theoretically should be related.

The paper also gave careful consideration on reliability by first ensuring that the data collection instrument was suitable to respondents, and second, assessing the internal consistency of the scale using Cronbach's Alpha. It was ensured that the language used in the questionnaire was clear to the respondents and hence the measurement instrument was suitable to them. A reliability analysis on the work environmentscale comprising five items showed that the questionnaire attained an acceptable reliability with Alpha coefficient $(\alpha)$ equal to 0.832 as indicated in table 1.0.The obtained Alpha was within the acceptable range as it was between 0.7 and 0.9 as suggested by Streiner (2003). Streiner (2003) recommended a maximum value of Alpha coefficient $(\alpha)$ of 0.9 as when it is above that it can be too highand point to redundancy among the items.

Table1. Reliability Statistics

\begin{tabular}{|r|c|r|}
\hline Cronbach's Alpha & $\begin{array}{c}\text { Cronbach's Alpha Based on } \\
\text { Standardized Items }\end{array}$ & N of Items \\
\hline .832 & & .833 \\
\hline
\end{tabular}


The Influence of Work Environment on Employee Retention: Empirical Evidence from Banking Institutions in Dar Es Salaam, Tanzania

It was further checked if Alpha coefficient could increase by removing some items in the questionnaire. The study retained all items as any deletion of an item would have resulted in a decrease in the Alpha coefficient. This is as postulated at Cronbach's Alpha if item deleted column in table 2.0.

Table2. Item-Total Statistics

\begin{tabular}{|c|c|c|r|r|r|}
\hline & $\begin{array}{c}\text { Scale Mean if } \\
\text { Item Deleted }\end{array}$ & $\begin{array}{c}\text { Scale Variance } \\
\text { if Item Deleted }\end{array}$ & $\begin{array}{c}\text { Corrected Item- } \\
\text { Total } \\
\text { Correlation }\end{array}$ & $\begin{array}{c}\text { Squared } \\
\text { Multiple } \\
\text { Correlation }\end{array}$ & $\begin{array}{c}\text { Cronbach's } \\
\text { Alpha if Item } \\
\text { Deleted }\end{array}$ \\
\hline WE4 & 14.31 & 10.160 & .651 & .427 & .792 \\
\hline WE10 & 14.41 & 10.139 & .699 & .515 & .780 \\
\hline WE11 & 14.65 & 10.395 & .612 & .430 & .804 \\
\hline WE13 & 14.34 & 9.648 & .641 & .330 & .796 \\
\hline WE2 & 14.48 & 10.663 & .558 & .818 \\
\hline
\end{tabular}

Keynote: $W E 2=$ Control over work, WE4 $=$ Supervisor relationship, $W E 10=$ Responsibility,

WE11 = Work itself, WE13 = Bank Reputation

\subsection{Hypothesis testing}

The objective of the paper was to test the hypothesis which state; Work Environment has significant influence on employee retention at the banking institutions in Dar es Salaam. Findings using binary logistic regression are as presented in the following tables.

Table3. Variables in the Equation

\begin{tabular}{|c|c|c|c|c|c|c|c|}
\hline \multicolumn{2}{|c|}{} & B & S.E. & Wald & Df & Sig. & $\operatorname{Exp}(\mathrm{B})$ \\
\hline Step 0 & Constant & -.360 & .113 & 10.209 & 1 & .001 & .698 \\
\hline
\end{tabular}

Table 3 pointed out a significant value (p) equal to 0.001 which is less than 0.05 . This implies that the predictor (work environment) makes a significant contribution in predicting employee retention. Hence, the hypothesis $\mathrm{H}$ is accepted. Further results of the study were also presented in table 4.

Table4. Variables in the Equation

\begin{tabular}{|c|c|c|c|c|c|c|c|c|c|}
\hline & \multirow[t]{2}{*}{ B } & \multirow[t]{2}{*}{ S.E. } & \multirow[t]{2}{*}{ Wald } & \multirow[t]{2}{*}{ Df } & \multirow[t]{2}{*}{ Sig. } & \multirow[t]{2}{*}{$\operatorname{Exp}(B)$} & \multicolumn{2}{|c|}{$95 \%$ C.I.for $\mathrm{EXP}(\mathrm{B})$} \\
\hline & & & & & & & & Lower & Upper \\
\hline \multirow{6}{*}{$\begin{array}{c}\text { Step } \\
1^{\mathrm{a}}\end{array}$} & WE4 & -.158 & .158 & .994 & 1 & .319 & .854 & .626 & 1.165 \\
\hline & WE10 & -.502 & .183 & 7.489 & 1 & .006 & .605 & .423 & .867 \\
\hline & WE13 & -.379 & .142 & 7.122 & 1 & .008 & .685 & .519 & .904 \\
\hline & WE11 & .092 & .163 & .317 & 1 & .574 & 1.096 & .796 & 1.510 \\
\hline & WE2 & .093 & .152 & .373 & 1 & .542 & 1.097 & .815 & 1.478 \\
\hline & Constant & 2.782 & .618 & 20.268 & 1 & .000 & 16.155 & & \\
\hline
\end{tabular}

Keynote: $W E 2$ =Control over work, WE4 = Supervisor relationship, $W E 10=$ Responsibility,

WE11 = Work itself, WE13 = Bank Reputation

The results provided in Table 4.0 showed that out of five indicators (indicator variables) only two indicators known as WE10 (responsibility) and WE13 (bank reputation) were statistically significant. From these results you can see that WE10 $(\mathrm{p}=.006)$ and WE13 $(\mathrm{p}=.008)$ added significantly to the model/prediction, but WE4 $(\mathrm{p}=.319)$, WE11 $(\mathrm{p}=.574)$ and WE2 $(\mathrm{p}=.542)$ did not add significantly to the model. Therefore, the hypothesis which state that, work environment has significant influence on employee retention is accepted. The hypothetical model developed from the findings is indicated in figure 2.0.

The insignificant attributes (indicators) of work environment were included in the derived model as these also can have influence on employee retention as some employees are very sensitive. This is due to the fact that employees are not the same as they have different sensitivity levels, satisfaction levels, altitudes, behaviours and perceptions as argued by Zareen, et al. (2013). Babyak (2004) suggest that non-significant values based on p-value alone does not mean no effect and that insignificant values can be important in some situations for example in deciding which parameters to include or not to include in an intervention programme to a public health problem. Similarly, Hirpara, et al. (2015) 
The Influence of Work Environment on Employee Retention: Empirical Evidence from Banking Institutions in Dar Es Salaam, Tanzania

argued that the presence of statistical significance does not necessarily mean clinically important when interpreting clinical research as the size of effect is the one that determines it.

Wald Chi-Squared Test for the insignificant attributes was also not zero as shown in table 4.0, this indicated that each insignificant attribute had some contribution to the model despite that it is small (Agresti, 1990, 2013). Hence, deleting insignificant indicator variables in the model would have resulted overfitting. Harrell $\mathrm{Jr}$ and Slaughter (2008) argued that removing indicators with little influence from the model results overfitting and hence an overfitted model. Similarly, Babyak (2004) contended that overfitting yields overly optimistic model results and the findings from the overfitted model do not really exist in the population and hence can't be replicated.
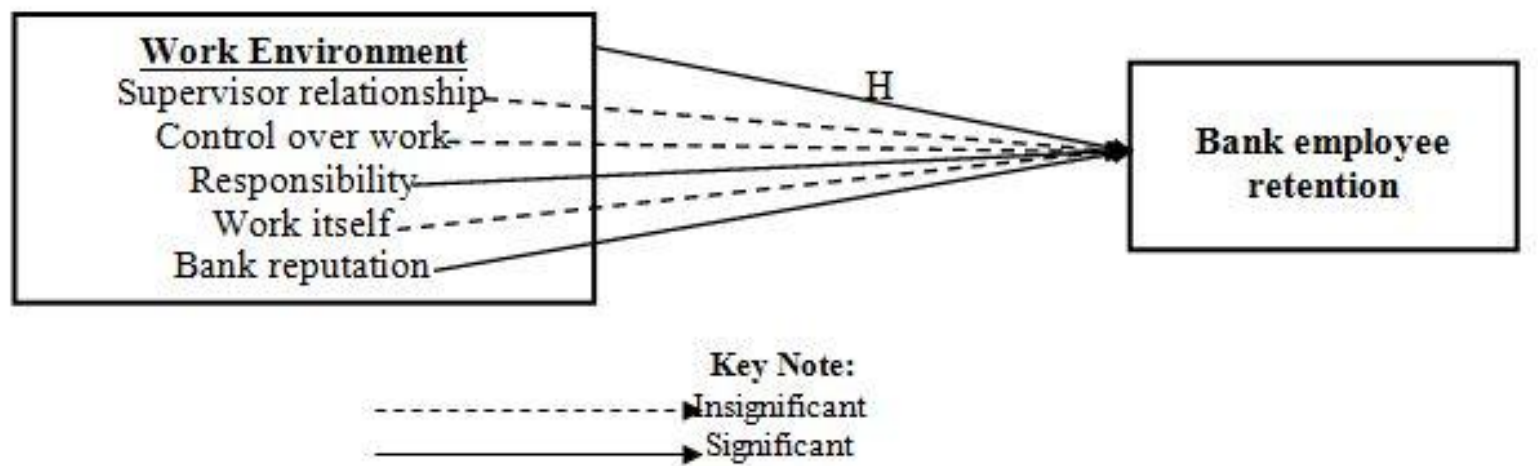

Figure8. Hypothetical Model of the Study

\section{DISCUSSION}

It was hypothesized by the study that work environment is significantly related to bank employee retention. In evaluating the relationship, the results yielded a significant value (p) of 0.001 for work environment. This indicates that work environment is significantly related to employee retention in the banking institutions in Dar es Salaam. The results of the study support the argument made based on Herzberg two factor theory that motivational factors such as work environment have positive and significant relationship on employee retention. In the same vein, the findings support the claims made by Oyagi and Kembu (2014) grounded on Herzberg two factor theory that motivational variables like work environment have positive and significant influence on retention of academic staff.

The findings corroborate with what Pek-Greer and Wallace (2017) who found that work environment has a significant influence on employee retention. Similarly, Mohamed, et al. (2017) indicated that work environment has strong influence on employee retention at an Agricultural Bank in Sudan. This implies that when employees are provided with conducive work environment at the work place, they are likely to stay instead of leaving the employing organization/bank. Therefore, the attributes of work environment that are most valued by employees in a particular organization/bank may be applied in encouraging employees to remain.

Previous studies by Patel and Patel (2014) and Gangwani and Dubey (2016) established a significant relationship between work environment and employee retention. This study shares some similar findings that, there is a link between work environment attributes such as responsibility for the job, control over work, supervisor relationship, work itself and bank reputation with employee retention. The results differ in respect of some of the variables. For instance, Msengeti and Obwogi (2015) found and reported the significant influence of work environment attributes, namely, supervisor relationship, opportunities to use initiatives and talents, working conditions and work- life balance while in the current study the opportunities to use initiatives and talents, working conditions and work- life balance were not supported.

The findings also show that not all elements of the work environment reward banks in retaining employees. For example, Jain and Kaur (2014) found that among eight work environment attributes, only five, that is, duties and responsibilities, refreshment and recreation facility, grievance handling, fun at workplace and health and safety facility were elements that influenced employee retention while attitude of supervisor, workload and overtime, job fatigue and boredom, showed no significant contribution in retaining employees. 
This implies that despite the significant influence of work environment on bank employee retention, but not all attributes that build up the work environment can have a significant influence on bank employees. The significant influence of the work environment depends on the degree to which those attributes reflect a particular environment. In this study, only two attributes of work environment, that is, responsibility (with p-value $=.006$ ) and bank reputation(with p-value $=.008$ ) were identified by the research model to explain bank employee retention whereas attributes namely control over work, supervisor relationship and work itself were found to be insignificantly related to employee retention.Results by Sharma, et al. (2018) indicated that responsibility has a positive impact on employee retention as when employees become more responsible for the job, they are motivated to stay in the organization. On the other hand, Gupta, et al. (2018) established a positive and significant relationship between organizational reputation and employee retention.

\section{CONCLUSION AND RECOMMENDATION}

The hypothesis on the influence of work environment on employee retention in the banking institutions in Dar es Salaam was tested and the model that can be used to explain employee retention specifically on work environment facets was developed. Grounded on employee retention literature, the study borrowed a factor from Herzberg dual factor theory to study employee retentionin the banking institutions. This paper confirms that work environmenthas significant influence on employee retention. This result can help bank managers who are looking forward to retain employees especially on work environment aspects. The paper reveals further that responsibility for the job and bank reputation are the most important attributes due to its significant contribution on employee retention. The bank management can consider this fact in developing and implementing work environmentpolicies. Additional research on the influence of work environment on employee retention can be conducted in other regions. The use of other data analysis techniques such as multiple regression and structural equation modeling can also be applied to study other parameters of employee retention.

\section{REFERENCES}

Adzei, F.A. and Atinga R.A. (2012). "Motivation and retention of health workers in Ghana's district hospitals: Addressing the critical issues". Journal of health organization and management. 26(4): 467 - 485.

Agresti, A. (1990). Categorical Data Analysis. New York: John Wiley and Sons.

Agresti, A. (2013). Categorical Data Analysis (3rd Ed). Hoboken: John Wiley \& Sons Inc.

Ahmada, N., Tariqb, M.S. and Hussain, A. (2015). Human resource practices and employee retention, evidences from banking sector of Pakistan. Journal of Business and Management Research.7:186 - 188.

Agyeman, C. M., and Ponniah, V. M. (2014). Employee Demographic characteristics and Their Effects on Turnover and Retention in MSMEs. International Journal of Recent Advances in Organizational Behaviour and Decision Sciences. 1(1), 12 - 29.

Bank of Tanzania (2017). Directorate of banking supervision Annual Report. Government Printer, Dar es Salaam, Tanzania.

[https://www.bot-tz.org/BankingSupervision/BankingSupervision.asp] site visited on 20/01/2019.

Babyak, M. A., and Green, S. M. (2010). Confirmatory factor analysis: an introduction for psychosomatic medicine researchers. Psychosomatic Medicine. 72(6), 587 - 597.

Chen, Y.S., Rasdi, R.M., Ismail, M. and Asmuni, A. (2017). Predictors of Intention to Stay and Moderating Role of Gender among Executives in the Malaysian Manufacturing Organizations. International Journal of Academic Research in Business and Social Sciences. 7(special issue).4th International Conference on Educational Research and Practice,Malaysia. [http://hrmars.com/hrmars_papers/Predictors_of_Intention_to_Stay_and_Moderating_Role_of_Gender_a mong_Executives_in_the_Malaysian_Manufacturing_Organizations.pdf] site visited on 12/05/2017.

Drost, E. A. (2011). Validity and Reliability in Social Science Research. Education Research and Perspectives. 38(1), $105-124$.

Gangwani, S. and Dubey, K. (2016). A study on Working Environment influencing Employee Retention of Indian IT Professionals. Journal of Applied Management Science. 2(7): 76 - 88.

Gayathri, R., Sivaraman, G. and Kamalambal, R. (2012). Employee retention strategies in BPO's - An empirical investigation. Interdisciplinary Journal of Contemporary Research in Business. 3(12): 572 - 583. 
The Influence of Work Environment on Employee Retention: Empirical Evidence from Banking Institutions in Dar Es Salaam, Tanzania

Gupta, R., Sahoo, S. K., and Sahoo, T. R. (2018). Employer Branding: A Tool for Employee Retention. International Journal of Business and Management Invention. 7(6), 06 - 12.

Harrell Jr, F. E., and Slaughter, J. C. (2008). Introduction to Biostatistics for Biomedical Research. [http://biostat.mc.vanderbilt.edu/wiki/pub/Main/Clin Stat/ci2.biostat1.pdf] site visited on 22/09/2019.

Herzberg, F. (1966). Work and the nature of man. Thomas Y. Crowell Company. New York.

Hirpara, N., Jain, S., Gupta, A. and Dubey, S. (2015). Interpreting research findings with confidence interval. Journal of Orthodontics and Endodontics. 1(8) $1-4$.

Hong, E.N., Hao, L.Z., Kumar, R., Ramendran, C. and Kadiresan, V. (2012). An effectiveness of human resource management practices on employee retention in institute of higher learning: - a regression analysis. International Journal of Business Research and Management. 3(2): 60 - 79.

Ibidunni, S., Osibanjo, O., Adeniji, A., Salau, O.P. and Falola, H. (2016). Talent Retention and Organizational Performance: A Competitive Positioning in Nigerian Banking Sector. Social and Management Sciences. 24(1): $1-13$.

Ihantola, E., and Kihn, L. (2011). Threats to Validity and Reliability in Mixed Methods Accounting Research. Qualitative Research in Accounting and Management. 8(1), 39 - 58.

Imna, M. and Hassan, Z. (2015). Influence of Human Resource Management practices on Employee Retention in Maldives Retail Industry. International Journal of Accounting, Business and Management. 1(1): 1 - 28.

Jain, R. and Kaur, S. (2014). Impact of Work Environment on Job Satisfaction. International Journal of Scientific and Research Publications. 4(1): 1- 8.

Kanwal, A. and Majid, M. (2013). Retention Management in Banking System An Evidence from Multan, Punjab Pakistan. Interdisciplinary Journal of Contemporary Research in Business. 5(1): 795 - 804.

Kimberlin, C. L., and Winterstein, A. G. (2008). Validity and reliability of measurement instruments used in research. American Journal of Health-System Pharmacists. 65(2), 2276 - 2284.

Kweka, N.A and Sedoyeka, E. (2014). Labor Turnover in Tanzania - Telecom vs Banking Sectors. International Journal of Computing and ICT Research. 8(2): 65 - 82.

Lancaster, G. (2005). Research Methods: A Concise Introduction to Research in Managements and Business Consultancy. Butterworth-Heinemann. London.

Malik, M.F., Akhtar, S. and Ghafoor, I. (2018). Supervisor Support, Co-Worker Support and Employee Retention: Developing and Testing of an Integrative Model. International Journal of Modern Social Sciences. 7(1): $1-24$.

Manogharan, M.W., Thivaharan, T. and Rahman, R.A. (2018). Academic staff retention in private higher education institute - case study of private colleges in Kuala Lumpur. International Journal of Higher Education. 7(3): $52-78$.

Markey, R., Ravenswood, K. and Webber, D.J. (2012). The impact of the quality of the work environment on employees' intention to quit. Economics Working Paper Series 1220.

[file://C:/Users/General/Downloads/1221\%20(4).pdf] site visited on 16/09/2016.

Mboya, W.J. (2012). Model for Determinants of Labour Mobility in the Banking Industry of Tanzania. The African Journal of Finance and Management. 21(2)

[http://journal.ifm.ac.tz/index.php/AJFM/article/view/51] site visited 22/06/2016.

Mir, A.A. and Mufeed, U. (2016). Employee Retention - A Key Tool for Achieving Competitive Advantage. International Journal of Engineering and Management Research. 6(6): 334 - 337.

Mohamed, R., Ngui, T.K. and Mulili, B. (2017). Factors Determining Employee Retention in the Banking Sector: A Case Study of Agricultural Bank of Sudan. Journal of Education \& Entrepreneurship. 4(10): 1 23.

Motlou, R.G. and Karodia, A.M. (2016). An evaluation of the impact of job satisfaction on employee retention at Lonmin Rowland Shaft North West province. Kuwait Chapter of Arabian Journal of Business and Management Review. 5(10): 15 - 49.

Msengeti, D.M. and Obwogi, J. (2015). Effects of Pay and Work Environment on Employee Retention: A Study of Hotel Industry in Mombasa County. International Journal of Scientific and Research Publications. 5(4): $2250-3153$.

Msisiri, P. R. and Juma, D. (2017). Relationship between non-financial rewards and retention of employees in banking industry: Case of Commercial Rural Development Bank-Arusha Tanzania. International Journal of Economics and Finance. 5(2): 1-38.

Muhoho, J.M.E. (2014). Assessment of factors influencing employee retention in Tanzania's work organizations. International journal of innovation and applied studies. 9(2): 687 - 697. 
The Influence of Work Environment on Employee Retention: Empirical Evidence from Banking Institutions in Dar Es Salaam, Tanzania

Mwita, K.M., Mwakasangula, E. and Tefurukwa, O. (2018). The Influence of Leadership on Employee Retention in Tanzania Commercial Banks. International Journal of Human Resource Studies. 8(2): 274 283.

Nasir, S.Z. and Mahmood, N. (2016). Determinants of Employee Retention: An Evidence from Pakistan. International Journal of Academic Research in Business and Social Sciences. 6(9): 182 - 194.

Oyagi, N.B. and Kembu, S.A. (2014). To assess the relationship between motivation and retention of academic staff in selected public higher institutions of learning in Dar es-Salaam. International journal of advancement in engineering technology, management and applied science. 1(4):54 - 61 .

Patel, N.R. and Patel, M.B. (2014). To Study the Impact of HR Practices on Employee Retention" - a Case Study of L \& T Ltd, Hazira, Surat. Indian Journal of Research. 3(8): 98 - 100.

Pek-Greer, P. and Wallace, M. (2017). A Study of Childcare Teacher Retention in the Childcare Service Industry. Global Business Review. 18(1): $71-86$.

Reddy, K. and Govender, K.K. (2014). Retaining knowledge workers: a case study of a leading South African bank. Mediterranean journal of social sciences. 5(23): 2768 - 2776.

Regina, C. Dy. and Rosalia, T.C. (2015). A Strategic Employee Retention Model Based on Employee Perception. European Journal of Business Management. 2 (5), 25-35.

Roy, B. (2018). Impact of work life balance on employee retention: a study on women employees working in banking sector with special reference to Jorhat city. International Research Journal. 1(26): 48-53

Samuel, M.O. and Chipunza, C. (2009). Employee retention and turnover: Using motivational variables as a panacea. African Journal of Business Management. 3(8): 410 - 415.

Shahin, N. (2017). A Study of Employee Retention in the Pharmaceuticals Sector in Ranchi City. International Journal of Engineering Technology Science and Research. 4(9): 292 - 301.

Sharma, M., Gupta, S., and Sharma, P. (2018). Impact of Employee Empowerment on Retention of Knowledge Workers in Higher Education Sector. International Journal of Research in Humanities, Arts and Literature. 6(4), 1 - 6.

Streiner, D. L. (2003). Statistical Developments and Applications, Starting at the Beginning: An Introduction to Coefficient Alpha and Internal Consistency. Journal of Personality Assessment. 80(1), 99 - 103.

Tansuria, B. I., and Nelwan, M. L. (2018). Exploratory Factors Analysis of Employee Retention at Tertiary Educational Institution: A Case Study of a Private University in East Indonesia. Binus Business Review. 9(3): 227 - 233.

Thirupathy, A. and Dhayalan, C. (2016). Employee retention and turnover using motivational variables at India. International Journal of Research. 4(8): 1 - 9.

Uitzinger, D., Chrysler-Fox, P., and Thomas, A. (2016). Retention Strategies for Top and Middle-level Managers. Proceedings of the 28th Annual Conference of the Southern African Institute of Management Scientists, Johannesburg, South Africa. September 2016. [https://www.researchgate.net/publication/ 307811720_Retention_strategies_for_top-and_middle-level_managers] site visited on 20/01/2019.

Waweru, S.W. and Kagiri, A. (2018). Effect of Human Resource Management Strategies on Employee Retention: A Survey of Agriculture sector Ngo's based in Nairobi, Kenya. The Strategic Journal of Business \& Change Management. 5(2): 2340 - 2360.

Zareen, M., Razzaq, K. and Ramzan, M. (2013). Impact of employee retention on performance: the moderating role of employee psychological perception towards retention plan. Interdisciplinary journal of contemporary research in business. 4(10): 822 - 830. 
The Influence of Work Environment on Employee Retention: Empirical Evidence from Banking Institutions in Dar Es Salaam, Tanzania

\section{AUTHOR'S BIOGRAPHY}

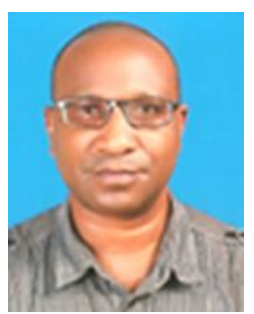

Dr. Amos Ephraim Hanai, is a Freelance Management Consultant - P.O. Box 68376 Dar es Salaam, Tanzania. He holds a PhD in Human Resource Management from the Open University of Tanzania. His research interests and areas of consultancy include employee retention, customer relationship management, evaluation studies such as policy/project evaluations, customer service, recruitment and selection, market research and feasibility studies.

Citation: Amos Ephraim Hanai "The Influence of Work Environment on Employee Retention: Empirical Evidence from Banking Institutions in Dar Es Salaam, Tanzania" International Journal of Managerial Studies and Research (IJMSR), vol 9, no. 1, 2021, pp. 42-54. doi: https://doi.org/10.20431/2349-0349.0901004.

Copyright: (C) 2021 Authors. This is an open-access article distributed under the terms of the Creative Commons Attribution License, which permits unrestricted use, distribution, and reproduction in any medium, provided the original author and source are credited. 